\title{
Anastrepha species (Diptera: Tephritidae), their host plants and parasitoids (Hymenoptera) in the state of Roraima, Brazil: state of the art
}

\author{
Alberto Luiz Marsaro Júnior ${ }^{1}$ \\ Ricardo Adaime $2 *$ \\ Beatriz Ronchi-Teles ${ }^{3}$ \\ Miguel Francisco de Souza-Filho ${ }^{4}$ \\ Paulo Roberto Valle da Silva Pereira ${ }^{1}$ \\ Elisângela Gomes Fidelis de Morais 5 \\ Rinaldo Joaquim da Silva Júnior 5 \\ Elizana da Silva e Silva ${ }^{6}$ \\ ${ }^{1}$ Embrapa Trigo, Rodovia BR 285, km 294, Caixa Postal 451 \\ CEP 99001-970, Passo Fundo - RS, Brazil \\ ${ }^{2}$ Embrapa Amapá, Rodovia JK, km 5, 2600, CEP 68903-419, Macapá - AP, Brazil \\ ${ }^{3}$ Instituto Nacional de Pesquisas da Amazônia \\ Avenida André Araújo, 2936, CEP 69067-375, Manaus - AM, Brazil \\ ${ }^{4}$ Instituto Biológico, Caixa Postal 70, CEP 13012-970, Campinas - SP, Brazil \\ ${ }^{5}$ Embrapa Roraima, BR 174, km 08, CEP 69301-970, Boa Vista - RR, Brazil \\ ${ }^{6}$ Faculdade Cathedral \\ Avenida Luís Canúto Chaves, 293, CEP 69307-053, Boa Vista - RR, Brazil \\ * Corresponding author \\ ricardo.adaime@embrapa.br
}

\section{Resumo}

Espécies de Anastrepha (Diptera: Tephritidae), suas plantas hospedeiras e parasitoides (Hymenoptera) no estado de Roraima, Brasil: o estado da arte. Esta revisão tem por objetivo atualizar as informações sobre as espécies de Anastrepha no estado de Roraima, com ênfase em sua distribuição, plantas hospedeiras e parasitoides. Atualmente estão registradas 25 espécies de Anastrepha e 27 espécies vegetais hospedeiras. Anastrepha striata e A. obliqua são as espécies mais amplamente distribuídas no estado. Anastrepha obliqua é a espécie mais polífaga, associada a 13 hospedeiros. Seis espécies de parasitoides estão registradas, sendo Doryctobracon areolatus o mais abundante e o que está associado ao maior número de espécies de Anastrepha.

Palavras-chave: Amazônia; Braconidae; Figitidae; Moscas-das-frutas 


\section{Abstract}

The aim of this review was to update the available information on Anastrepha species in the state of Roraima, Brazil, with emphasis on distribution, host plants and parasitoids. In total, 25 species of Anastrepha and 27 host plant species have been recorded to date in Roraima. Anastrepha striata and A. obliqua are widely distributed in the state. Anastrepha obliqua is the most polyphagous species, where it is associated with 13 hosts. Six species of parasitoids of Anastrepha have been reported in Roraima. Of these, Doryctobracon areolatus is the most abundant and has been associated with the largest number of Anastrepha species.

Key words: Amazon; Braconidae; Figitidae; Fruit flies

\section{Introduction}

The state of Roraima is located in the extreme north of the Brazilian Amazon, occupying an area of $224,299 \mathrm{~km}^{2}$ between latitudes $5^{\circ} 16^{\prime} \mathrm{N}$ and $1^{\circ} 25^{\prime} \mathrm{S}$; and longitudes $58^{\circ} 55^{\prime} \mathrm{W}$ and $64^{\circ} 48^{\prime} \mathrm{W}$ (IBGE, 2010a), corresponding to $2.6 \%$ of the Brazilian territory and $5.3 \%$ of the Amazon biome (FUNCATE, 2006). It is the Brazilian state with the smallest number of municipalities (15), although some of them cover large territories, such as the municipality of Caracaraí $(47,411$ $\mathrm{km}^{2}$ ). Roraima has international borders with Venezuela and Guyana. Within Brazil, it borders the states of Amazonas and Pará.

In Roraima, there are three climate groups according to the Köppen classification system: Aw, Af, and Am. The Aw climate region corresponds to the savannas in central-eastern and northeastern Roraima. This type of climate is characterized by a marked, well-defined dry period, which is between the months of December and March. Mean annual rainfall in this region is $1,655 \pm 408$ $\mathrm{mm}$. Approximately $9 \%$ of this total occurs at the peak of the dry season (December-March), and 70\% at the peak of the rainy season (May-August) (BARBOSA, 1997; ARAÚJO et al., 2001). The Af climate is observed in the forest systems of the extreme south and northwest parts of the state. These regions are predominantly covered by dense ombrophilous forests, with mean annual rainfall exceeding 2,000 $\mathrm{mm}$. The Am type climate is found in the contiguous forests and grassland regions of the state, where mean annual rainfall ranges from 1,700 to $2,000 \mathrm{~mm}$.]

Fruit farming is a very important source of revenue and employment in Roraima. The main fruit crops are banana, papaya, orange, lime, pineapple, melon and watermelon (IBGE, 2010b). In addition to these crops, a wide variety of native and exotic fruit trees can be found in home orchards, many of which are known to be or are potential hosts of fruit flies (MARSARO JÚNIOR et al., 2011b).

Fruit flies (Diptera: Tephritidae) are among the most important pest species in the world, due to their direct economic impact and the severe quarantine restrictions enforced by many countries to prevent their entry into their territories (ALUJA, 1994; ALUJA; MANGAN, 2008). The family Tephritidae is composed of approximately 4,541 valid species grouped into 493 genera (NORRBOM, 2010). Anastrepha Schiner is considered the most economically relevant fruit fly genus in tropical America, with over 250 described species and the highest recorded number of pest species (NORRBOM, 2004a; 2004b; NORRBOM et al., 2014). To date, 120 species of Anastrepha have been reported in Brazil (ZUCCHI, 2008). Six of these are particularly important from an economic standpoint: Anastrepha striata Schiner, A. obliqua (Macquart), A. fraterculus (Wiedemann), A. grandis (Macquart), A. pseudoparallela (Loew), and A. zenildae Zucchi (URAMOTO; ZUCCHI, 2009).

The first survey of Anastrepha species in Roraima was conducted in the 1990s by Rafael (1991), who recorded three species at the time: A. leptozona Hendel, A. hamata (Loew), and A. serpentina (Wiedemann). In that study, the only reported host plant was Pouteria caimito, hosting A. leptozona. No parasitoid species were reported. In 2000, Malavasi and Zucchi (2000) published a book gathering all the available information on fruit flies in Brazil. In the chapter dedicated to northern Brazil, 
Silva and Ronchi-Teles (2000) reported that eight species of Anastrepha, only five species of host plants and no species of parasitoids had been registered in Roraima. In addition, only localized collection efforts had been conducted in the state, covering only four municipalities.

Starting in 2007, through the project known as the Amazonian Network for Research on Fruit Flies, coordinated and funded by the Brazilian Agricultural Research Corporation (Embrapa), a new series of surveys was initiated with the goal of investigating the diversity of Anastrepha species, as well as their host plants and parasitoids in Roraima. When the project was completed, all available information on fruit flies in the Brazilian Amazon was consolidated in a book (SILVA et al., 2011b). In that work, Marsaro Júnior et al. (2011b) updated the number of Anastrepha species recorded in Roraima (17). New studies conducted after that time (MARSARO JÚNIOR et al., 2011a; 2012; 2013a; 2013b; ZUCCHI et al., 2011a; ADAIME et al., 2012; LIMA et al., 2012; TRASSATO et al., 2015) expanded the existing knowledge about fruit flies in Roraima, where 25 species of Anastrepha, 27 species of host plants and six species of parasitoids have been reported to date.

The aim of this review was to update current knowledge of Anastrepha species in Roraima, with emphasis on their distribution, host plants and parasitoids.

\section{Anastrepha species richness and distribution}

As shown in Figure 1, the number of Anastrepha species recorded in Roraima since the earliest studies by Rafael (1991) has risen from three in 1991 to 25 today, with the recent publications by Lima et al. (2012) and Marsaro Júnior et al. (2013a; 2013b). This leap in the number of reported species was unquestionably the result of the surveys conducted during the Amazonian Network for Research on Fruit Flies project, initiated in 2007.

Anastrepha striata is the most widely distributed species in Roraima (Table 1). This species is very well adapted to conditions found in the state and can be collected both at low altitudes - such as the state capital

FIGURE 1: Cumulative curve of number of Anastrepha species recorded in Roraima, considering reports up to and including the respective years shown.

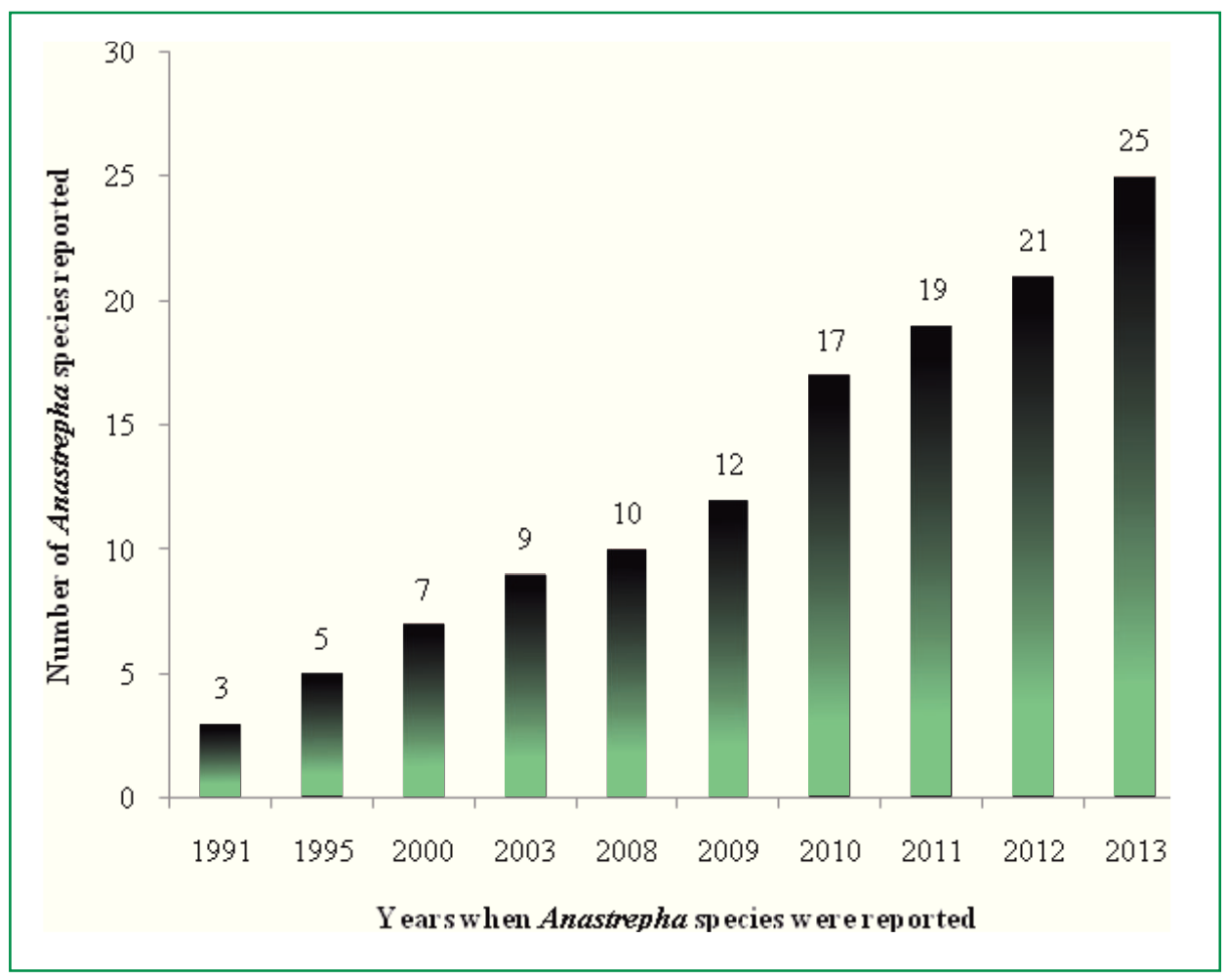


Boa Vista (approximately $100 \mathrm{~m}$ above sea level [masl]) - and at higher elevations, such as Pacaraima, located above 900 masl (MARSARO JÚNIOR et al., 2012). According to Aluja (1994), the level of dominance of a species is influenced by ecological bases (host plant, richness and diversity) and by altitudinal gradients. In Mexico, for example, in mango orchards at 1,100 masl, $30 \%$ of all collected individuals were $A$. ludens (Loew), out of 14 species captured in traps. At lower altitudes (680 m), among 12 captured species, only $4 \%$ of individuals were $A$. ludens. Therefore, given that $A$. striata is well adapted to different altitudes in Roraima and provided that host plants are available, this species may be present in every municipality in the state, and has indeed been reported in 13 of 14 municipalities already sampled. Anastrepha striata is also the most widely distributed species in the state of Amapá (SILVA et al., 2011a) and is present in every state of the Brazilian Amazon (ZUCCHI et al., 2011b).

Anastrepha obliqua, also widely distributed in Roraima, has been reported in 12 municipalities within the state (Table 1). This distribution can be explained by the polyphagous habits of the species, whose main hosts are fruits of Anacardiaceae and Myrtaceae, which are very common in Roraima, as shown by Marsaro Júnior et al. (2011a). Anastrepha obliqua is also present in every

TABLE 1: Anastrepha species and their distribution in 14 municipalities of the state of Roraima.

\begin{tabular}{|c|c|c|c|c|c|c|c|c|c|c|c|c|c|c|}
\hline \multirow{2}{*}{ Species* } & \multicolumn{14}{|c|}{ Municipalities } \\
\hline & BV & AM & PA & $\mathrm{CC}$ & BO & CA & NO & MU & IR & RO & SJ & SL & CR & UI \\
\hline Anastrepha amita Zucchi, 1979 & & $\mathrm{X}^{\mathrm{a}}$ & & & & & & & & & & & & \\
\hline Anastrepha antunesi Lima, 1938 & $\mathrm{X}^{\mathrm{b}}$ & $\mathrm{X}^{\mathrm{a}}$ & $\mathrm{X}^{\mathrm{c}}$ & & & & & & & & & & & \\
\hline Anastrepha atrigona Hendel, 1914 & $\mathrm{X}^{\mathrm{b}}$ & & & & & & & $X^{d}$ & & & & & & $\mathrm{X}^{\mathrm{e}}$ \\
\hline Anastrepha bahiensis Lima, 1937 & $X^{f}$ & & $\mathrm{X}^{\mathrm{c}}$ & & $\mathrm{X}^{\mathrm{c}}$ & $\mathrm{X}^{\mathrm{g}}$ & & & & & & & & \\
\hline Anastrepha coronilli Carrejo \& González, 1993 & & $X^{\mathrm{a}}$ & $\mathrm{X}^{\mathrm{e}}$ & & & $\mathrm{X}^{\mathrm{c}}$ & & & & & & & & \\
\hline Anastrepha distincta Greene, 1934 & $X^{f}$ & $\mathrm{X}^{\mathrm{a}}$ & $\mathrm{X}^{\mathrm{c}}$ & $\mathrm{X}^{\mathrm{q}}$ & $\mathrm{X}^{\mathrm{h}}$ & $\mathrm{X}^{\mathrm{c}}$ & $\mathrm{X}^{\mathrm{d}}$ & & $\mathrm{X}^{\mathrm{r}}$ & $\mathrm{X}^{\mathrm{p}}$ & & & & \\
\hline Anastrepha ethalea (Walker, 1849) & $\mathrm{X}^{\mathrm{i}}$ & & & & & & & & & & & & & \\
\hline Anastrepha flavipennis Greene, 1934 & $X^{\mathrm{f}}$ & & & & $X^{d}$ & & & & & & & & & \\
\hline Anastrepha fractura Stone, 1942 & $\mathrm{X}^{\mathrm{b}}$ & & & & & & & & & & & & & \\
\hline Anastrepha fraterculus (Wiedemann, 1830) & $\mathrm{X}^{\mathrm{b}}$ & & & & & & & & & & & & & \\
\hline Anastrepha hamata (Loew, 1873) & & $\mathrm{X}^{\mathrm{j}}$ & & & & & & & & & & & & \\
\hline Anastrepha leptozona Hendel, 1914 & $\mathrm{X}^{\mathrm{b}}$ & $\mathrm{X}^{\mathrm{j}}$ & & & & & & & & & & & & \\
\hline Anastrepha longicauda Lima, 1934 & & $\mathrm{X}^{\mathrm{b}}$ & & & & & & & & & & & & \\
\hline Anastrepha manihoti Lima, 1934 & & $X^{a}$ & $\mathrm{X}^{\mathrm{c}}$ & $\mathrm{X}^{\mathrm{q}}$ & & & $\mathrm{X}^{\mathrm{c}}$ & & & & & & & \\
\hline Anastrepha montei Lima, 1934 & & & $\mathrm{X}^{\mathrm{c}}$ & & & & & & & & & & & \\
\hline Anastrepha obliqua (Macquart, 1835) & $X^{d}$ & $X^{a}$ & $\mathrm{X}^{\mathrm{c}}$ & $\mathrm{X}^{\mathrm{q}}$ & $X^{d}$ & $X^{c}$ & $\mathrm{X}^{\mathrm{d}}$ & $X^{g}$ & $\mathrm{X}^{\mathrm{r}}$ & $\mathrm{X}^{\mathrm{p}}$ & $\mathrm{X}^{\mathrm{p}}$ & $\mathrm{X}^{\mathrm{p}}$ & & \\
\hline Anastrepha parishi Stone, 1942 & $X^{\mathrm{k}}$ & & & $\mathrm{X}^{\mathrm{q}}$ & & & & $X^{p}$ & & & & & & \\
\hline Anastrepha rafaeli Norrbom \& Korytkowski, 2009 & & $\mathrm{X}^{1}$ & & $\mathrm{X}^{\mathrm{q}}$ & & & & & & & & & & \\
\hline Anastrepha serpentina (Wiedemann, 1830) & $X^{d}$ & $X^{j}$ & $\mathrm{X}^{\mathrm{c}}$ & & & & $\mathrm{X}^{\mathrm{d}}$ & & & & & & & \\
\hline Anastrepha sororcula Zucchi, 1979 & $\mathrm{X}^{\mathrm{c}}$ & $\mathrm{X}^{\mathrm{a}}$ & $\mathrm{X}^{\mathrm{c}}$ & & $X^{f}$ & & & & & & & & & \\
\hline Anastrepha striata Schiner, 1868 & $\mathrm{X}^{\mathrm{c}}$ & $\mathrm{X}^{\mathrm{a}}$ & $\mathrm{X}^{\mathrm{h}}$ & $X^{g}$ & $X^{d}$ & $\mathrm{X}^{\mathrm{c}}$ & $\mathrm{X}^{\mathrm{d}}$ & $X^{d}$ & $\mathrm{X}^{\mathrm{r}}$ & $\mathrm{X}^{\mathrm{p}}$ & $X^{s}$ & $\mathrm{X}^{\mathrm{p}}$ & $\mathrm{X}^{\mathrm{p}}$ & \\
\hline Anastrepha turpiniae Stone, 1942 & $\mathrm{X}^{\mathrm{m}}$ & & & & & & & & & & & & & \\
\hline Anastrepha zenildae Zucchi, 1979 & $\mathrm{X}^{\mathrm{n}}$ & & $X^{f}$ & $\mathrm{X}^{\mathrm{p}}$ & & $\mathrm{X}^{\mathrm{p}}$ & & & & & & & & \\
\hline Anastrepha zernyi Lima, 1934 & $\mathrm{X}^{\mathrm{f}}$ & & & & & & & & & & & & & \\
\hline Anastrepha zucchii Norrbom, 1998 & & $\mathrm{X}^{\mathrm{o}}$ & & & & & & & & & & & & \\
\hline Total species per municipality & 17 & 14 & 11 & 7 & 6 & 6 & 5 & 4 & 3 & 3 & 2 & 2 & 1 & 1 \\
\hline
\end{tabular}

AM: Amajari, BV: Boa Vista, BO: Bonfim, CA: Cantá, CC: Caracaraí, CR: Caroebe, IR: Iracema, MU: Mucajaí, NO: Normandia, PA: Pacaraima, RO: Rorainópolis, SJ: São João da Baliza, SL: São Luiz, UI: Uiramutã. References: ${ }^{a}$ Marsaro Júnior et al. (2010), 'arsaro Júnior et al. (2013a), ${ }^{\mathrm{c}}$ Marsaro Júnior et al. (2011a), ${ }^{\mathrm{d} A m o r i m ~(2003), ~}{ }^{\mathrm{e} S i l v a}$ and Ronchi-Teles (2000), ${ }^{\mathrm{f}}$ Marsaro Júnior et al. (2012), ${ }^{\mathrm{g}}$ Silva Júnior et

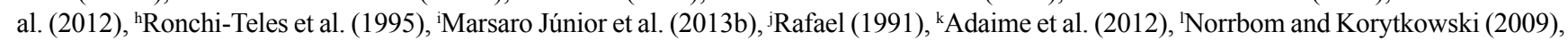
${ }^{\mathrm{m}}$ Lima et al. (2012), ${ }^{\mathrm{n}}$ Ronchi-Teles et al. (2008), ${ }^{\circ}$ Norrbom (1998), ${ }^{\mathrm{p} S}$ Silva et al. (2016a), ${ }^{\mathrm{q}}$ Silva et al. (2016b), ${ }^{\mathrm{r}}$ Silva Júnior et al. (2016a), ${ }^{\mathrm{s}}$ Silva Júnior et al. (2016b). * Considering only the first report of each Anastrepha species in each municipality, collected from fruit or by trapping. 
state within the area known as the "Legal Amazon." It is able to adapt to a variety of biomes and occurs practically throughout Brazil, except in the state of Sergipe, where it has not been reported to date (ZUCCHI et al., 2011b).

Fruit fly surveys have been conducted in the central (Boa Vista and neighboring municipalities), northern, northeastern and southern regions of Roraima (Figure 2). The municipalities with the highest species richness are those where surveying has been most intense and frequent, including Boa Vista, Amajari and Pacaraima, whereas the lowest richness levels were found at locations where only localized collection efforts were made (Table 1; Figure 2).

FIGURE 2: Number of Anastrepha species recorded in municipalities of the state of Roraima.

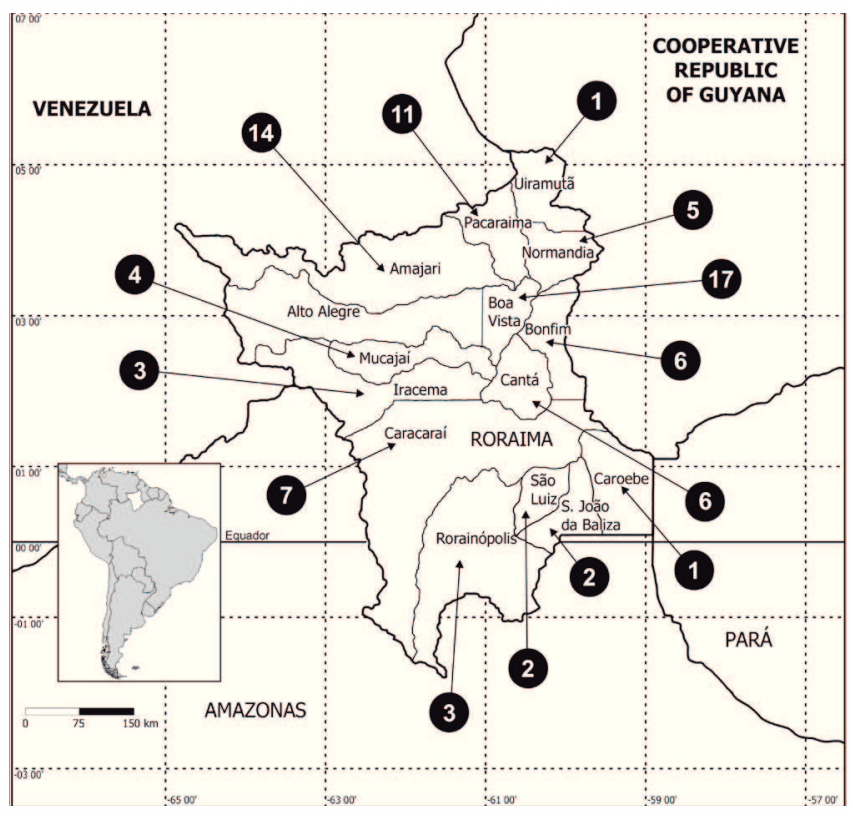

Figure 2 shows that surveys have been performed in 14 out of 15 municipalities in Roraima, and new information has recently been obtained regarding the distribution of Anastrepha species in municipalities located in the southern part of the state, expanding their known distribution ranges. However, for an accurate view of Anastrepha distribution and richness throughout the state of Roraima, new surveys should be completed in the less studied municipalities, and particularly in Alto Alegre, which has not been sampled to date.

The state capital Boa Vista has the highest known richness of Anastrepha (17 species), followed by
Amajari (14) and Pacaraima (11). The lowest richness levels are found in Caroebe and Uiramutã, with a single species each (Table 1). The high richness of Anastrepha species observed in Boa Vista is mainly due to the fact that the majority of surveys conducted in Roraima, with fruit sampling and McPhail traps, have focused mainly on the capital, as shown by the works of Marsaro Júnior et al. (2011a; 2012; 2013a; 2013b) and Lima et al. (2012). The number of Anastrepha species in Boa Vista is likely to be even higher; the faunistic analysis conducted in this municipality by Marsaro Júnior et al. (2012) showed that the observed species richness was lower than expected, since the cumulative species curves indicated moderate growth, suggesting that the collection effort was not sufficient to produce an accurate description of species richness in Boa Vista. This shows that surveying should be continued in all municipalities in Roraima, to improve the accuracy of available data on Anastrepha species richness throughout the state.

\section{Host plants of Anastrepha}

The state of Roraima features a wide diversity of native and exotic fruit trees, many of which are known to be or are potential hosts of Anastrepha (MARSARO JÚNIOR et al., 2011b). To date, 27 plant species have been reported as hosts of Anastrepha spp., across 12 botanical families (Table 2).

Families Myrtaceae and Anacardiaceae account for over $50 \%$ of all known hosts of Anastrepha in Roraima (Figure 3). Anastrepha obliqua is the most polyphagous Anastrepha, having been associated with 13 host plants from four botanical families (Table 2). However, Anastrepha obliqua has a marked preference for Anacardiaceae and Myrtaceae hosts, and the main host plant of this species is Spondias spp. (MARSARO JÚNIOR et al., 2011a; 2011b). In Roraima, S. mombin has shown one of the highest rates of infestation by $A$. obliqua, with up to 345 puparia/kg of fruit (MARSARO JÚNIOR et al., 2011a).

In a report by Marsaro Júnior et al. (2012), Anastrepha obliqua was considered a dominant species in the municipalities of Bonfim and Pacaraima, and super-dominant in Boa Vista. It is also believed to be 
the most abundant fruit fly in the state of Tocantins (BOMFIM et al., 2007) and the most relevant in the state of Amazonas (RONCHI-TELES; SILVA, 2005).

Anastrepha striata is the second most polyphagous Anastrepha species in Roraima, having been associated with 10 host plant species from five botanical families (Table 2). However, it has a strong preference for Myrtaceae host plants, with Psidium guajava as its main host (MARSARO JÚNIOR et al., 2011a; 2013b). The same has been observed in the state of Amapá (SILVA et al., 2011a; JESUS-BARROS et al., 2012). Anastrepha striata has been considered dominant in Bonfim and Pacaraima and super-dominant in Boa Vista (MARSARO JÚNIOR et al., 2012). In the state of Amapá, A. striata is believed to be the most polyphagous and widely distributed fruit fly and, therefore, one of the top three in terms of economic importance (DEUS; ADAIME, 2013).

TABLE 2: Anastrepha species associated with their host plants in the state of Roraima.

\begin{tabular}{|c|c|c|c|}
\hline \multirow{2}{*}{ Anastrepha species* } & \multicolumn{2}{|r|}{ Hosts } & \multirow{2}{*}{ References } \\
\hline & Families & Species (common names in Portuguese) & \\
\hline Anastrepha amita & Verbenaceae & Citharexylum poeppigii ${ }^{2}$ & Marsaro Júnior et al. (2010) \\
\hline Anastrepha antunesi & Anacardiaceae & Spondias mombin (taperebá) ${ }^{2}$ & Marsaro Júnior et al. (2010) \\
\hline \multirow[t]{2}{*}{ Anastrepha bahiensis } & Myrtaceae & Psidium guineense (araçá-do-campo) ${ }^{2}$ & Marsaro Júnior et al. (2011a) \\
\hline & Rosaceae & Eriobotrya japonica (nêspera) ${ }^{1}$ & Marsaro Júnior et al. (2011a) \\
\hline Anastrepha coronilli & Melastomataceae & $\begin{array}{l}\text { Bellucia grossularioides (goiaba-de-anta) } \\
\text { Loreva mespiloides }^{2}\end{array}$ & $\begin{array}{l}\text { Silva and Ronchi-Teles (2000) } \\
\text { Marsaro Júnior et al. (2010) }\end{array}$ \\
\hline \multirow[t]{5}{*}{ Anastrepha distincta } & Anacardiaceae & Anacardium occidentale (caju) ${ }^{2}$ & Silva et al. (2016a) \\
\hline & Fabaceae & Inga edulis (ingá-cipó) ${ }^{2}$ & Ronchi-Teles et al. (1995) \\
\hline & & Inga laurina (ingá-caruru) ${ }^{2}$ & Marsaro Júnior et al. (2011a) \\
\hline & & Inga thibaudiana (ingá) ${ }^{2}$ & Marsaro Júnior et al. (2010) \\
\hline & Myrtaceae & Psidium guajava (goiaba) ${ }^{1}$ & Silva et al. (2016a) \\
\hline Anastrepha leptozona & Sapotaceae & Pouteria caimito (abiu) $)^{2}$ & Rafael (1991) \\
\hline Anastrepha manihoti & Euphorbiaceae & Manihot esculenta (mandioca) ${ }^{2}$ & Marsaro Júnior et al. (2010) \\
\hline Anastrepha montei & Euphorbiaceae & Manihot esculenta (mandioca) ${ }^{2}$ & Marsaro Júnior et al. (2011a) \\
\hline \multirow[t]{13}{*}{ Anastrepha obliqua } & Anacardiaceae & Anacardium occidentale (caju) ${ }^{2}$ & Marsaro Júnior et al. (2011a) \\
\hline & & Spondias dulcis (cajá-manga) ${ }^{1}$ & Amorim (2003) \\
\hline & & Spondias mombin (taperebá) ${ }^{2}$ & Marsaro Júnior et al. (2010) \\
\hline & & Spondias purpurea (seriguela) ${ }^{1}$ & Marsaro Júnior et al. (2011a) \\
\hline & & Spondias sp. (umbu-cajá) ${ }^{3}$ & Marsaro Júnior et al. (2011a) \\
\hline & Malpighiaceae & Malpighia emarginata (acerola) ${ }^{1}$ & Amorim (2003) \\
\hline & Myrtaceae & Eugenia stipitata (araçá-boi) ${ }^{2}$ & Marsaro Júnior et al. (2011a) \\
\hline & & Eugenia uniflora (pitanga) ${ }^{2}$ & Marsaro Júnior et al. (2010) \\
\hline & & Myrciaria cauliflora (jabuticaba) ${ }^{2}$ & Marsaro Júnior et al. (2011a) \\
\hline & & Psidium acutangulum (araçá-pêra) ${ }^{2}$ & Marsaro Júnior et al. (2011a) \\
\hline & & Psidium guajava (goiaba) ${ }^{1}$ & Amorim (2003) \\
\hline & & Psidium sp. (araçá) ${ }^{2}$ & Marsaro Júnior et al. (2011a) \\
\hline & Oxalidaceae & Averrhoa carambola (carambola) ${ }^{1}$ & Marsaro Júnior et al. (2011a) \\
\hline \multirow[t]{2}{*}{ Anastrepha parishi } & Anacardiaceae & Spondias purpurea (seriguela) ${ }^{1}$ & Silva et al. (2016a) \\
\hline & Myrtaceae & Myrciaria dubia (camu-camu) ${ }^{2}$ & Adaime et al. (2012) \\
\hline Anastrepha serpentina & Sapotaceae & Pouteria caimito (abiu) $)^{2}$ & Silva and Ronchi-Teles (2000) \\
\hline \multirow[t]{4}{*}{ Anastrepha sororcula } & Myrtaceae & Myrciaria cauliflora (jabuticaba) ${ }^{2}$ & Marsaro Júnior et al. (2011a) \\
\hline & & Psidium guajava (goiaba) ${ }^{1}$ & Marsaro Júnior et al. (2010) \\
\hline & & Psidium guineense (araçá-do-campo) ${ }^{2}$ & Marsaro Júnior et al. (2010) \\
\hline & & Syzygium sp. (jambo) ${ }^{1}$ & Marsaro Júnior et al. (2011a) \\
\hline \multirow[t]{10}{*}{ Anastrepha striata } & Anacardiaceae & Anacardium occidentale (caju) ${ }^{2}$ & Silva et al. (2016a) \\
\hline & & Spondias mombin (taperebá) ${ }^{2}$ & Marsaro Júnior et al. (2011a) \\
\hline & & Spondias purpurea (seriguela) ${ }^{1}$ & Silva Júnior et al. (2016a) \\
\hline & Malpighiaceae & Malpighia emarginata (acerola) ${ }^{1}$ & Silva et al. (2016a) \\
\hline & Myrtaceae & Psidium acutangulum (araçá-pêra) ${ }^{2}$ & Silva and Ronchi-Teles (2000) \\
\hline & & Psidium guajava (goiaba) ${ }^{1}$ & Ronchi-Teles et al. (1995) \\
\hline & & Psidium guineense (araçá-do-campo) ${ }^{2}$ & Amorim (2003) \\
\hline & & Psidium sp. $(\text { araçá })^{2}$ & Marsaro Júnior et al. (2011a) \\
\hline & Oxalidaceae & Averrhoa carambola (carambola) $)^{1}$ & Silva et al. (2016a) \\
\hline & Passifloraceae & Passiflora edulis (maracujá) ${ }^{2}$ & Silva and Ronchi-Teles (2000) \\
\hline \multirow[t]{3}{*}{ Anastrepha zenildae } & Malpighiaceae & Malpighia emarginata (acerola) ${ }^{1}$ & Silva et al. (2016a) \\
\hline & Myrtaceae & Psidium guajava (goiaba) ${ }^{1}$ & Marsaro Júnior et al. (2011a) \\
\hline & Rhamnaceae & Ziziphus mauritiana (dão) ${ }^{1}$ & Ronchi-Teles et al. (2008) \\
\hline
\end{tabular}

*Considering only the first record of Anastrepha species in the host. ${ }^{1}$ Exotic species; ${ }^{2}$ Native species; ${ }^{3}$ Origin unknown. 
FIGURE 3: Number of hosts of Anastrepha in each botanical family and respective percentages in relation to total number of hosts.

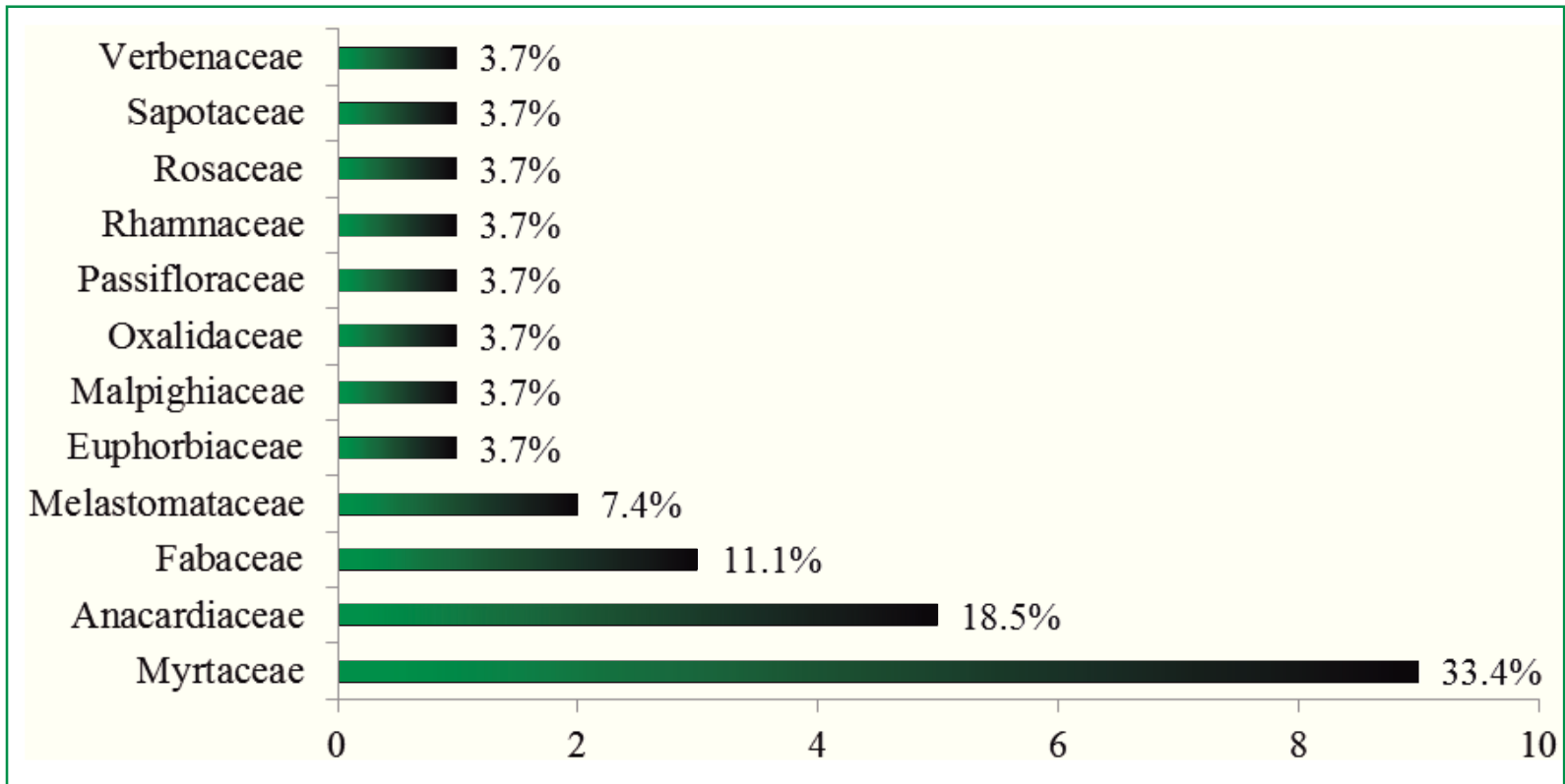

This means that, in terms of distribution, dominance and polyphagy, A. obliqua and A. striata are the most economically important Anastrepha species in the state of Roraima.

Some species of Anastrepha can be classified as specialists, infesting one specific host. One example is A. manihoti, whose larvae develop exclusively in fruits of Manihot esculenta (Euphorbiaceae) (Table 2). As a result, $A$. manihoti has a more limited distribution and has been reported only at locations where fruits of its only known host are present. To date in the Brazilian Amazon, A. manihoti has been observed only in the states of Amazonas and Rondônia (RONCHI-TELES, 2000) and Roraima (MARSARO JÚNIOR et al., 2011b).

Polyphagous species are more widely distributed than specialist ones and they often show niche overlap, with multiple species using the same host plant (MALAVASI; MORGANTE, 1980). This strategy can be viewed in Table 2, which shows multiple species of Anastrepha occurring on the same host plants.

Eleven species of Anastrepha in Roraima have had no hosts reported thus far (Table 3). Six of these species are exclusive to the Amazon and one of them, A. zucchii, only occurs in the state of Roraima (ZUCCHI et al., 2011b). In other states in the Amazon region, hosts of
A. atrigona, $A$. fractura, $A$. fraterculus and $A$. turpiniae have been known for some time, as listed by Zucchi et al. (2011b) and shown in Dutra et al. (2013). But for some other species, such as A. flavipennis, a host plant in the Amazon region (Pouteria glomerata, Sapotaceae) has been reported only recently (CORRÊA et al., 2011).

TABLE 3: Anastrepha without known host plants in the state of Roraima.

\begin{tabular}{l}
\multicolumn{1}{c}{ Anastrepha species } \\
\hline Anastrepha atrigona* \\
Anastrepha ethalea \\
Anastrepha flavipennis \\
Anastrepha fractura* \\
Anastrepha fraterculus \\
Anastrepha hamata* \\
Anastrepha longicauda* \\
Anastrepha rafaeli* \\
Anastrepha turpiniae \\
Anastrepha zernyi \\
Anastrepha zucchii* \\
\hline
\end{tabular}

*Species exclusive to the Amazon

Other species, including A. ethalea, A. hamata, $A$. longicauda, A. rafaeli, A. zernyi, and A. zucchii, have no known hosts in the Brazilian Amazon (ZUCCHI, 2008; ZUCCHI et al., 2011b). To identify the host plants of these Anastrepha species, new studies should therefore 
be conducted not only in Roraima, but across the entire Brazilian Amazon.

Some hosts of Anastrepha in Roraima are exotic species (Table 2) grown mainly in urban areas. The most extensive areas of the Amazon Forest in Roraima, with their huge diversity of native fruits, are found mostly in the southern part of the state, where few fruit fly surveys have been conducted. Studies conducted in this region could lead to new reports of Anastrepha species and their host plants. We therefore suggest that any new surveys of Anastrepha in Roraima should focus on this poorly studied part of the state.

\section{Natural enemies of Anastrepha spp.}

The first study into the diversity of parasitoids of Anastrepha spp. in Roraima was conducted by RonchiTeles (2000), who reported two species: Doryctobracon areolatus (Szépligeti) and Doryctobracon brasiliensis (Szépligeti). A number of additional studies were subsequently conducted and new species were reported, making up a current total of six known parasitoid species (Table 4).
Doryctobracon areolatus is the most abundant parasitoid of Anastrepha and has been associated with the highest number of Anastrepha species (eight) (Table 4). Doryctobracon crawfordi (Viereck), which has been reported in Brazil only in the states of Amapá and Roraima so far (ZUCCHI et al., 2011a), has been associated with two species in Roraima, namely $A$. coronilli and A. serpentina (Table 4).

With regard to $D$. brasiliensis (Szépligeti), reported in Roraima by Ronchi-Teles (2000), additional studies are needed to confirm if this species is associated with A. leptozona or A. serpentina, since these two fruit flies emerged from the same host fruit. The only known parasitoid of Anastrepha belonging to the family Figitidae, Aganaspis pelleranoi (Brèthes), is associated with A. obliqua (Table 4).

The highest rate of parasitism of Anastrepha observed in Roraima (62.3\%) was seen in fruits of the native plant Loreya mespiloides (Melastomataceae) (MARSARO JÚNIOR et al., 2010). That study showed the importance of native plants in preserving and multiplying the populations of these agents of biological control of fruit flies, and further highlights the need for

TABLE 4: Parasitoid species associated with Anastrepha spp. in the state of Roraima.

\begin{tabular}{|c|c|c|}
\hline $\begin{array}{c}\text { Families } \\
\text { Scientific names }\end{array}$ & Anastrepha spp. & References \\
\hline \multicolumn{3}{|l|}{ Braconidae } \\
\hline \multirow{8}{*}{ Doryctobracon areolatus (Szépligeti, 1911) } & A. amita & Marsaro Júnior et al. (2010) \\
\hline & A. coronilli & Ronchi-Teles (2000), Marsaro Júnior et al. (2010) \\
\hline & A. distincta & Marsaro Júnior et al. (2011a) \\
\hline & A. manihoti & Marsaro Júnior et al. (2010) \\
\hline & A. obliqua & Amorim (2003), Marsaro Júnior et al. (2011a) \\
\hline & A. serpentina & Marsaro Júnior et al. (2011a) \\
\hline & A. striata & Marsaro Júnior et al. (2011a) \\
\hline & A. zenildae & Ronchi-Teles et al. (2008), Marsaro Júnior et al. (2011a) \\
\hline Doryctobracon brasiliensis (Szépligeti, 1911) & $\begin{array}{l}\text { A. leptozona } \\
\text { A. serpentina }\end{array}$ & Ronchi-Teles (2000) \\
\hline \multirow{2}{*}{ Doryctobracon crawfordi (Viereck, 1911) } & A. coronilli & Marsaro Júnior et al. $(2010)^{*}$, Zucchi et al. (2011a) ${ }^{* *}$ \\
\hline & A. serpentina & Marsaro Júnior et al. (2011a), Zucchi et al. (2011a) \\
\hline \multirow{2}{*}{ Opius bellus Gahan, 1930} & A. manihoti & Marsaro Júnior et al. (2010) \\
\hline & A. obliqua & Marsaro Júnior et al. (2011a) \\
\hline Utetes anastrephae (Viereck, 1913) & A. obliqua & Marsaro Júnior et al. (2011a) \\
\hline \multicolumn{3}{|l|}{ Figitidae } \\
\hline Aganaspis pelleranoi (Brèthes, 1924) & A. obliqua & Marsaro Júnior et al. (2011a) \\
\hline
\end{tabular}

* Doryctobracon crawfordi is cited as Doryctobracon sp.2;**A. coronilli is cited as Anastrepha sp. 
conserving the native plant species of the Amazon, the natural habitat of these parasitoids.

Predators, especially spiders, are also important natural enemies of fruit flies in Roraima, as reported by Marsaro Júnior et al. (2011b), who observed the predation of $A$. amita by the spider Phiale crocea (Salticidae).

Therefore, in light of the sparseness of studies conducted in southern Roraima, more intensive surveys conducted in that region are likely to report new parasitoids or predators of Anastrepha, or may even reveal new species of Anastrepha and their natural enemies that are yet to be discovered, described and preserved.

\section{Final considerations}

Knowledge about fruit flies in the state of Roraima has seen major progress since the initial study on the topic was published in the early 1990s. The number of reported Anastrepha species in the state jumped from three to 25, the number of parasitoids from zero to six, and the number of host fruits from one to 27. Species distribution across the state is also better known now, with information currently available for 14 of the 15 municipalities of Roraima.

As previously mentioned, the state of Roraima features multiple types of plant formations (savannas, Amazon Forest and grasslands) and has borders with two Brazilian states (Amazonas and Pará) and two South American countries (Venezuela and Guyana). This geographic area as a whole is the site of reports of fruit flies of quarantine importance, a large number of preserved areas (conservation areas and indigenous reserves) and a wide variety of native and exotic fruit trees. Due to these peculiar characteristics, Roraima has major potential for studies on the bioecology of fruit flies, and the research conducted to date is still insufficient to fully express the existing richness of Anastrepha, parasitoids and host plants in the state. Fruit fly surveying should therefore continue (in already studied areas) and be extended to unsurveyed areas, to more accurately characterize the richness and distribution of fruit fly species, their host plants and parasitoids in the state of Roraima.

On the other hand, to ensure the success of additional fruit fly surveys in Roraima, human resources must be trained to perform these activities in the different plant formations found in the state. Access to these plant formations is difficult due to lack of supporting infrastructure, inadequate conservation and absence of roads in the interior of Roraima, not to mention the high volume of rain from May to August, which makes certain regions inaccessible in that period. However, these difficulties should not discourage fruit fly surveying in Roraima, especially in less studied areas. Creativity, effort and perseverance in finding solutions to overcome these access impediments will be rewarded through the wealth of knowledge that is waiting to be revealed in these regions of the state.

In recent years, several municipalities in Roraima have invested in the production of native and exotic fruits for local consumption and for distribution to other Brazilian states. This creates a need for studies oriented towards a more adequate management of tephritids that infest fruits of commercial interest.

Therefore, due to the importance of fruit farming for Roraima and the damages caused by tephritids to fruits in the state, further studies on fruit flies in the region are needed.

\section{Acknowledgments}

We thank Embrapa for funding the Amazonian Network for Research on Fruit Flies project. We are also grateful to the Brazilian Council for Scientific and Technological Development (CNPq) for the Research Productivity Fellowships granted to R. Adaime and M. F. de Souza-Filho. Dr. A. Leyva helped with English editing of the manuscript.

\section{References}

ADAIME, R.; MARSARO JÚNIOR, A. L.; SOUZA-FILHO, M. F.; CHAGAS, E. A.; LIMA, C. G. B. New host of Anastrepha parishi Stone (Diptera: Tephritidae) reported in Brazil. Brazilian Journal of Biology, São Carlos, v. 72, n. 1, p. 227, 2012. 
ALUJA, M. Bionomics and management of Anastrepha. Annual Review of Entomology, Palo Alto, v. 39, p. 155-178, 1994.

ALUJA, M.; MANGAN, R. L. Fruit fly (Diptera: Tephritidae) host status determination: critical conceptual, methodological, and regulatory considerations. Annual Review of Entomology, Palo Alto, v. 53, p. 473-502, 2008.

AMORIM, J. E. L. Diversidade de espécies de Anastrepha (Diptera: Tephritidae), seus parasitóides e hospedeiros em quintais agroflorestais no estado de Roraima. 2003. $51 \mathrm{f}$. Dissertation (Master in Agrarian Sciences) - Federal University of Amazonas, Manaus. 2003.

ARAÚJO, W. F.; ANDRADE-JÚNIOR, A. S.; MEDEIROS, R. D.; SAMPAIO, R. A. Precipitação pluviométrica mensal provável em Boa Vista, estado de Roraima, Brasil. Revista Brasileira de Engenharia Agrícola e Ambiental, Campina Grande, v. 5, n. 3, p. 563-567, 2001.

BARBOSA, R. I. Distribuição das chuvas em Roraima. In: BARBOSA, R. I.; FERREIRA, E. J. G.; CASTELLÓN, E. G. (Ed.). Homem, ambiente e ecologia no estado de Roraima. Manaus: INPA, 1997. p. 325-335.

BOMFIM, D. A.; UCHÔA-FERNANDES, M. A.; BRAGANÇA, M. A. L. Biodiversidade de moscas-das-frutas (Diptera, Tephritoidea) em matas nativas e pomares domésticos de dois municípios do estado do Tocantins, Brasil. Revista Brasileira de Entomologia, Curitiba, v. 51, p. 217-223, 2007.

CORRÊA, E. C.; SILVA, N. M.; SILVA, F. C. C.; PENA, M. R. First record of Anastrepha flavipennis Greene (Diptera: Tephritidae) and of its host in the Brazilian Amazon. Neotropical Entomology, Londrina, v. 40, n. 4, p. 517-518, 2011.

DEUS, E. G.; ADAIME, R. Dez anos de pesquisas sobre moscasdas-frutas (Diptera: Tephritidae) no estado do Amapá: avanços obtidos e desafios futuros. Biota Amazônia, Macapá, v. 3, n. 3, p. 157-168, 2013.

DUTRA, V. S.; RONCHI-TELES, B.; GARCIA, M. V. B.; ADAIME, R.; SILVA, J. G. Native hosts and parasitoids associated with Anastrepha fractura and other species (Diptera: Tephritidae) in the Brazilian Amazon. Florida Entomologist, Lutz, v. 96, n. 1, p. 270-273, 2013.

FUNCATE. Uso e cobertura da terra na floresta amazônica: PROBIO subproject 106/2004. 2006. Available at <http://mapas. mma.gov.br/geodados/brasil/vegetacao/vegetacao2002/amazonia/ documentos/relatorio_final.pdf>. Viewed on: 31 October 2009.

IBGE - INSTITUTO BRASILEIRO DE GEOGRAFIA E ESTATÍSTICA. Roraima - Synthesis. 2010a. Available at $<$ http:// www.ibge.gov.br/estadosat/perfil.php?sigla $=\mathrm{rr}>$. Viewed on: 21 June 2010 .

IBGE - INSTITUTO BRASILEIRO DE GEOGRAFIA E ESTATÍSTICA. Produção agrícola municipal: informações sobre culturas temporárias e permanentes. 2010b. Available at: $<$ http:// www.sidra.ibge.gov.br/bda/pesquisas/pam/default.asp $>$. Viewed on: 27 March 2010.

JESUS-BARROS, C. R.; ADAIME, R.; OLIVEIRA, M. N.; SILVA, W. R.; COSTA-NETO, S. V.; SOUZA-FILHO M. F. Anastrepha (Diptera: Tephritidae) species, their hosts and parasitoids (Hymenoptera: Braconidae) in five municipalities of the State of Amapá, Brazil. Florida Entomologist, Lutz, v. 95, n. 3, p. 694$705,2012$.
LIMA, A. B.; LIMA, A. C. S; OLIVEIRA, A. H. C.; SANTOS, N. S. Ocorrência de moscas-das-frutas (Diptera: Tephritidae) em mangueiras (Mangifera indica L.) em Boa Vista, Roraima. Revista Agro@mbiente On-line, Boa Vista, v. 6, n. 2, p. 179-183, 2012.

MALAVASI, A.; MORGANTE, J. S. Biologia de "moscas-dasfrutas" (Diptera: Tephritidae). II. Índices de infestação em diferentes hospedeiros e localidades. Revista Brasileira de Biologia, São Carlos, v. 40, n. 1, p. 17-24, 1980.

MALAVASI, A.; ZUCCHI, R. A. Moscas-das-frutas de importância econômica no Brasil: conhecimento básico e aplicado. Ribeirão Preto: Holos, 2000. 327 p.

MARSARO JÚNIOR, A. L.; ADAIME, R.; RONCHI-TELES, B.; LIMA, C. R.; PEREIRA, P. R. V. S. Anastrepha species (Diptera: Tephritidae), their hosts and parasitoids in the extreme north of Brazil. Biota Neotropica, Campinas, v. 11, n. 4, p.117-123, 2011 a. MARSARO JÚNIOR, A. L.; ADAIME, R.; SOUZA-FILHO, M. F.; LIMA, C. R.; TRASSATO, L. C. Anastrepha fruit flies (Diptera: Tephritidae) from two municipalities of the state of Roraima, Brazil, with three new records. Revista de Agricultura, Piracicaba, v. 88, n. 1 , p. 41-43, $2013 \mathrm{a}$.

MARSARO JÚNIOR, A. L.; DEUS, E. G.; RONCHI-TELES, B.; ADAIME, R.; SILVA JÚNIOR, R. J. Species of Anastrepha (Diptera: Tephritidae) captured in a guava orchard (Psidium guajava L., Myrtaceae) in Boa Vista, Roraima, Brazil. Brazilian Journal of Biology, São Carlos, v. 73, n. 4, p. 879-886, 2013 b.

MARSARO JÚNIOR, A. L.; NASCIMENTO, D. B.; RONCHITELES, B.; ADAIME, R. Faunistic analysis of the species of Anastrepha Schiner (Diptera: Tephritidae) in three municipalities of the state of Roraima, Brazil. Brazilian Journal of Biology, São Carlos, v. 72, n. 4, p. 813-819, 2012.

MARSARO JÚNIOR, A. L.; RONCHI-TELES, B.; BARBOSA, R. I.; SILVA JÚNIOR, R. J.; AGUIAR, R. M.; SILVA, R. A. Conhecimento sobre moscas-das-frutas no estado de Roraima. In: SILVA, R. A.; LEMOS, W. P.; ZUCCHI, R. A. (Ed.). Moscasdas-frutas na Amazônia brasileira: diversidade, hospedeiros e inimigos naturais. Macapá: Embrapa Amapá, 2011b. p. 279-290.

MARSARO JÚNIOR, A. L.; SILVA, R. A.; SILVA, W. R.; LIMA, C. R.; FLORES, A. S.; RONCHI-TELES, B. New records of Anastrepha (Diptera: Tephritidae), its hosts and parasitoids in the Serra do Tepequém, Roraima state, Brazil. Revista de Agricultura, Piracicaba, v. 85, n. 1, p. 15-19, 2010.

NORRBOM, A. L. A revision of the Anastrepha daciformis species group (Diptera: Tephritidae). Proceedings of the Entomological Society of Washington, Washington, v. 100, n. 1, p. 160-192, 1998.

NORRBOM, A. L. Updates to biosystematics database of World Diptera for Tephritidae through 1999. Diptera Data Dissemination Disk (CD-ROM), 2. 2004a.

NORRBOM, A. L. Host plant database for Anastrepha and Toxotrypana (Diptera: Tephritidae: Toxotrypanini). Diptera Data Dissemination Disk (CD-ROM), 2. 2004b.

NORRBOM, A. L. Tephritidae (Fruit flies, moscas de frutas). In: BROWN, B. V.; BORKENT, A.; CUMMING, J. M.; WOOD, D. M.; WOODLEY, N. E.; ZUMBADO, M. A. (Ed.). Manual of Central American Diptera. Vol. 2. Ottawa: NRC Research Press, 2010. p. 909-954. 
NORRBOM, A. L.; CASTILLO-MEZA, A. L.; GARCÍACHÁVEZ, J. H.; ALUJA, M.; RULL, J. A new species of Anastrepha (Diptera: Tephritidae) from Euphorbia tehuacana (Euphorbiaceae) in Mexico. Zootaxa, Auckland, v. 3780, p. 567-576, 2014.

NORRBOM, A. L.; KORYTKOWSKI, C. A. A revision of the Anastrepha robusta species group (Diptera: Tephritidae). Zootaxa, Auckland, v. 2182, p. 1-91, 2009.

RAFAEL, J. A. Insetos coletados durante o Projeto Maracá, Roraima, Brasil: lista Complementar. Acta Amazonica, Manaus, v. 21, p. 325-336, 1991.

RONCHI-TELES, B. Ocorrência e flutuação populacional de espécies de moscas-das-frutas e parasitóides, com ênfase para o gênero Anastrepha (Diptera: Tephritidae) na Amazônia brasileira. 2000. $157 \mathrm{f}$. Thesis (Doctorate) - INPA/UA, Manaus. 2000 .

RONCHI-TELES, B.; MARSARO JÚNIOR, A. L.; LOVATO, L.; SILVA, R. A. Ocorrência de Anastrepha zenildae Zucchi (Diptera: Tephritidae) e seu parasitóide em frutos de Ziziphus mauritiana (Rhamnaceae) em Roraima. In: CONGRESSO BRASILEIRO DE ENTOMOLOGIA, 22, 2008, Uberlândia, Resumos... Uberlândia: SEB, 2008. Available online at $<$ https:// www.alice.cnptia.embrapa.br/alice/bitstream/doc/353168/1/ AP2008ocorrenciaanastrephazenildae.pdf $>$.

RONCHI-TELES, B.; SILVA, N. M. Flutuação populacional de espécies de Anastrepha Schiner (Diptera: Tephritidae) na região de Manaus, AM. Neotropical Entomology, Londrina, v. 34, n. 5, p. 733-741, 2005.

RONCHI-TELES, B.; ZUCCHI, R. A.; SILVA, N. M. Novos registros de espécies de Anastrepha (Dip. Tephritidae) e seus hospedeiros no estado de Roraima. In: CONGRESSO BRASILEIRO DE ENTOMOLOGIA, 15, ENCONTRO NACIONAL DE FITOSSANITARISTAS, 6, SIMPÓSIO INTEGRADO DE MANEJO DE PRAGAS, 2, 1995, Caxambu, Resumos... Lavras: ESAL, 1995. p. 239. Available online at $<$ http://ainfo.cnptia.embrapa.br/digital/bitstream/item/148038/1/ ID43776-1995CBEp239.pdf>.

SILVA, E. S.; MORAIS, E. G. F.; SILVA JÚNIOR, R. J.; SOUZAFILHO, M. F.; ANDRADE, P. C. R.; SANTOS, W. N. Primeiro relato de moscas-das-frutas (Diptera: Tephritidae) e seus hospedeiros em sete municípios de Roraima. In: CONGRESSO BRASILEIRO DE ENTOMOLOGIA/CONGRESSO LATINO-AMERICANO DE ENTOMOLOGIA, 26/10, 2016, Maceió. Anais... Maceió: Embrapa, 2016a. p. 574.

SILVA, E. S.; MORAIS, E. G. F.; SILVA JÚNIOR, R. J.; SOUZAFILHO, M. F.; LOVATO, L. Espécies de moscas-das-frutas (Diptera: Tephritidae) capturadas em armadilhas McPhail no município de Caracaraí, Roraima. In: CONGRESSO BRASILEIRO DE ENTOMOLOGIA/CONGRESSO LATINO-AMERICANO DE ENTOMOLOGIA, 26/10, 2016, Maceió. Anais... Maceió: Embrapa, 2016b. p. 574.

SILVA, N. M.; RONCHI-TELES, B. Moscas-das-frutas nos estados brasileiros: Amapá, Amazonas, Pará, Rondônia e Roraima. In: MALAVASI, A.; ZUCCHI, R. A. (Ed.). Moscas-das-frutas de importância econômica no Brasil: conhecimento básico e aplicado. Ribeirão Preto: Holos, 2000. p. 203-209.
SILVA, R. A.; DEUS, E. G.; PEREIRA, J. D. B.; JESUS, C. R.; SOUZA-FILHO, M. F.; ZUCCHI, R. A. Conhecimento sobre moscas-das-frutas no estado do Amapá. In: SILVA, R. A.; LEMOS, W. P.; ZUCCHI, R. A. (Ed.). Moscas-das-frutas na Amazônia brasileira: diversidade, hospedeiros e inimigos naturais. Macapá: Embrapa Amapá, 2011a. p. 223-236.

SILVA, R. A.; LEMOS, W. P.; ZUCCHI, R. A. Moscas-das-frutas na Amazônia brasileira: diversidade, hospedeiros e inimigos naturais. Macapá: Embrapa Amapá, 2011b. 299 p.

SILVA JÚNIOR, R. J.; FERNANDES, J. L.; MORAIS, E. G. F. Levantamento das espécies de moscas-das-frutas, inimigos naturais e seus hospedeiros no município de Iracema - Roraima. In: CONGRESSO BRASILEIRO DE ENTOMOLOGIA/ CONGRESSO BRASILEIRO DE ENTOMOLOGIA/ CONGRESSO LATINO-AMERICANO DE ENTOMOLOGIA, 26/10, 2016, Maceió. Anais... Maceió: Embrapa, 2016a. p. 215.

SILVA JÚNIOR, R. J.; MARSARO JÚNIOR, A. L.; ADAIME, R.; RONCHI-TELES, B. Novos registros de Anastrepha spp. (Diptera: Tephritidae) e de parasitoides (Hymenoptera: Braconidae) para o estado de Roraima. In: CONGRESSO BRASILEIRO DE ENTOMOLOGIA, 24, 2012, Curitiba. Resumos... Curitiba: SEB, 2012. Available online at: <http://seb.web2130.uni5.net/asp/ cbe2012/trabalhos/910/910_1.pdf >.

SILVA JÚNIOR, R. J.; MORAIS, E. G. F.; SANTOS, W. N.; ANDRADE, P. C. R.; SILVA, E. S. Levantamento da diversidade de moscas-das-frutas (Diptera: Tephritidae) no monitoramento de Bactrocera carambolae no sul do estado de Roraima. In: CONGRESSO BRASILEIRO DE ENTOMOLOGIA/ CONGRESSO LATINO-AMERICANO DE ENTOMOLOGIA, 26/10, 2016, Maceió. Anais... Maceió: Embrapa, 2016b. p. 484.

TRASSATO, L. B.; LIMA, A. C. S.; MONTEIRO NETO, J. L. L.; BANDEIRA, H. F. S.; SILVA, E. S.; STRÜCKER, A. Flutuação populacional de Anastrepha striata (Diptera: Tephritidae) em pomares comerciais de goiabeira. Revista Agro@mbiente Online, Boa Vista, v. 9, n. 3, p. 317-326, 2015.

URAMOTO, K.; ZUCCHI, R. A. Taxonomia de espécies de Anastrepha (Diptera: Tephritidae). In: MALAVASI, A.; VIRGINIO, J. (Ed.). Biologia, monitoramento e controle: V Curso Internacional de Capacitação em Moscas-das-frutas. Juazeiro: MOSCAMED, 2009. p. 7-11.

ZUCCHI, R. A. Fruit flies in Brazil - Anastrepha species, their host plants and parasitoids. 2008. Available at: <http://www.lea. esalq.usp.br/anastrepha/>. Viewed on: 18 December 2016.

ZUCCHI, R. A.; MARINHO, C. F.; SILVA, R. A. First record of the fruit fly parasitoid Doryctobracon crawfordi (Viereck) (Hymenoptera: Braconidae) in Brazil. Neotropical Entomology, Londrina, v. 40, n. 6, p. 711-712, 2011a.

ZUCCHI, R. A.; SILVA, R. A.; DEUS, E. G. Espécies de Anastrepha e seus hospedeiros na Amazônia brasileira. In: SILVA, R. A.; LEMOS, W. P.; ZUCCHI, R. A. (Ed.). Moscas-das-frutas na Amazônia brasileira: diversidade, hospedeiros e inimigos naturais. Macapá: Embrapa Amapá, 2011b. p. 51-70. 